\title{
5 Arthur Inman ${ }^{15}$
}

Arthur Inman was born on May $11^{\text {th }} 1895$ in Atlanta, Georgia, the only child of rich and prominent residents. He died by shooting himself on December $5^{\text {th }} 1963$ in his home in Boston. He left a diary of approximately 17 million words, some of which has been typed and microfilmed. An abbreviated version of the diary was edited by Daniel Aaron and published (Aaron, 1985), amounting to 1599 printed pages in two volumes. Aaron accomplished an incredibly difficult task and is to be commended for his effort.

Unfortunately from the point of view of a suicidologist, Aaron was a Professor of English and American Literature and Language, and he chose what to include in the published volumes on the basis of throwing light on the social and political events of the time, albeit from one person's perspective. In particular, the edited extracts end in 1951 on page 1526, and the last 12 years of the diary are omitted except for very brief extracts of no more than a few pages. The missing years are probably of little interest to a social historian, but crucial to a psychologist trying to understand the reasons for Inman's suicide. This chapter is a qualitative analysis of the parts of the diary that have been published.

There have been four brief commentaries on Inman, and most of the commentators disliked the man. Aaron (1985) called him a "repulsive weakling," Shneidman (1994) talked of his repellent attitudes and warped personality, while Maltsberger (Leenaars \& Maltsberger, 1994) described him as selfishly indulgent and corrupt. I disagree. If any of us kept as detailed and honest a diary as Inman did (17 million words in some 50 years), recording every one of our thoughts, desires, emotions and dreams, none of us would appear to be “nice” individuals. Inman's attitudes and desires can be found in most people, but others do not record them for us to read. For example, of course Inman was a racist and a sexist, but so were most people born in the South in the 1890s (as well as in the $20^{\text {th }}$ and $21^{\text {st }}$ Centuries all across America). Had he stayed in Atlanta and become a successful businessman, he might well have joined other similar men and co-founded the Augusta National Golf Club! Indeed his political views (such as liking Joseph McCarthy and disliking Franklin Roosevelt) can be found today in commentators such as Ann Coulter.

In this chapter, I will first briefly described Inman's life and then try to understand the reasons for his suicide, except that I think that the interesting question is not why did he kill himself, but rather why did he not kill himself much earlier in life. I am often impressed by how long suicides live rather than puzzled by their deaths. For this essay, I have based my analysis on the two-volume published edition of the diary (Aaron, 1985) and commentaries by Leenaars and Maltsberger (1994) and by Shneidman (1994).

15 This chapter is based on Lester (2010b).

(c) BY-NC-ND (C) 2014 David Lester.

This work is licensed under the Creative Commons Attribution-NonCommercial-NoDerivs 3.0 License 


\subsection{Inman's Life}

Inman went to local schools until he was 13 whereupon his parents sent him to board at the Haverford School outside of Philadelphia where he was bullied and spent five miserable years. The bullying seems to be have been traumatic for Inman, although he did not have a breakdown until his college years. It has been well-documented that bullying can have a serious impact on mental health (Srabstein, 2008) including suicidality (Kim 2008).

His parents then sent him to Haverford College, although he would have preferred to begin a career back in Atlanta. Despite enjoying college life to some extent, he had a physical and nervous breakdown in his third year and dropped out. There may have been some experiences at college which re-aroused the trauma of the earlier bullying at school, but Inman does not mention any in his diary which he began a few years later. He stayed in Boston for the rest of his life, convinced that he was very sick and treated by a team of osteopaths who realigned his bones and organs, pumped his stomach, administered enemas and prescribed several dangerous chemicals for him (especially bromides). His father supported him financially, although not excessively but upon, his father's death in 1951, Arthur inherited substantial assets. From 1920 on, he lived permanently in an apartment in Garrison Hall in the Back Bay area of Boston where he paid a succession of staff to assist him as he lived out his life in darkened rooms, sound-proofed as best he could. They cooked for him, massaged him, read to him and told him about their lives. Some let him cuddle them, caress them and have sexual intercourse with them. He met Evelyn Yates, a student at Wellesley College, and married her in 1923. They remained married (with occasional separations) until his suicide in 1963.

\subsection{Inman's Illnesses}

Musto (1985) read Inman's diary and provided a medical opinion on his health. The idea of auto-intoxication, that bacteria in the intestines were responsible for many illnesses, was a popular view in that era. Elie Mechnikoff, who was awarded the Nobel Prize for medicine in 1908, believed it, and it was an accepted medical theory. The osteopathic theory that misalignment of bones was responsible for many ailments was, however, not accepted by the medical establishment at that time.

Musto saw Inman's breakdown in 1916 as brought on by some minor medical problems which "allowed him to achieve some deep wishes to be alone but cared for” (p. 1609). Indeed, a year before his breakdown, Inman wrote that this was what he desired. Musto thought that Inman may have had "loose joints" but saw no reason why this would have caused pain and disability. Musto saw most of Inman's physical ailments as the result of his excessive ingestion of bromides and barbiturates prescribed by his "doctors" and his somewhat excessive use of alcohol. Bromide 
intoxication results in blurred vision, disordered sleep, and headaches, all of which Inman complained. Musto concluded that Inman did suffer from migraine headaches, hemorrhoids and nasal allergies, but the rest of his ailments could be attributed to his substance abuse and the medical maltreatment (especially the enemas with corrosive chemicals, stomach pumpings, and the ultraviolet radiation of his throat which resulted in sores).

\subsection{Psychiatric Diagnosis}

Maltsberger (Leenaars \& Maltsberger, 1994) diagnosed Inman's breakdown at college in 1916 as a major depressive disorder with symptoms of crying fits, loss of energy, difficulty sleeping, loss of appetite and low self-respect. The result was a regression with Oedipal overtones-a close attachment to his mother with the father excluded. A psychiatrist whom Inman consulted in 1918 suggested that Inman be separated from his mother and placed in a sanitarium. According to Maltsberger, Inman encouraged his wife to socialize with his osteopath, "Dr. Pike" (with whom, unbeknownst to Inman at the time, she had an affair), and then tried to break up their relationship, thereby recreating and, this time, successfully resolving his Oedipal conflict (albeit unconsciously) by getting his wife back. Maltsberger, therefore, speculated that a significant trauma (which remains unknown to us) occurred for Inman between the ages of 3 and 6.

Leenaars (Leenaars \& Maltsberger, 1994) focused on Inman's childhood as documented in the diary: a difficult birth, a domineering but loving mother, a father who wanted a girl, verbal and physical abuse from his father, and a horrible experience for five years at a boarding school far from home (from the ages of 13 to 18). Inman hated his father but loved his mother. On the other hand, there were no major traumata experienced by Inman in his early years until he was sent off to boarding school.

Maltsberger thought that Inman's mother was neurasthenic and that Inman identified with her. Indeed, Inman himself noted that she kept a diary and liked to advise and counsel others, just as he did (pp. 1569-1570). His depression appears to have persisted, resulting in suicidal behavior in 1941 and 1963. Maltsberger also diagnosed a narcissistic personality disorder. Maltsberger noted that Inman behaved as a small child, expecting the prerogatives accorded children. He was incapable of sustaining friendships but paid an array of servants and people to keep him company and run his errands. He was not only exploitive and selfish but also a psychological voyeur. He paid young women to come to his darkened bedroom where he probed their minds and caressed their bodies.

Maltsberger found no signs of psychosis in Inman, except for possible delusional ideas about his body, ideas which were promulgated by his osteopaths. Maltsberger felt that Inman's suicide was carried out in a state of acute visual hallucinosis that 
verged on delirium tremens caused by acute alcohol-barbiturate withdrawal possibly complicated by bromide poisoning.

\subsection{An Analysis of Arthur Inman}

\subsubsection{Social and Political Views}

Inman disliked Jews and African-Americans and wrote many derogatory passages about them. He also disliked the English, Irish and Slavs and even blue-eyed people! Yet one of his closest friends was an African-American woman, and his friendship with her changed his views considerably. Indeed what is remarkable in his diary is that Inman was able to admit occasionally the irrationality of his views and was able to find good qualities in some of those groups he disliked. There are also groups whom he admired, such as the Chinese and the Japanese.

He had strong political views (a style Aaron called a "paranoid style" of political thinking) and ended up disliking (even hating) most of the Presidents during his life. He admired "strong" leaders, even writing admiringly of Hitler, but he also admired Ghandi. However, he was quite clear that he would have hated to live as a German under Hitler. He was strongly anti-Communist, supported Joseph McCarthy's effort to root out Communists from the American government, and saw Stalin as a great danger to the world. These views were not atypical at the time, or even now, and do not indicate psychopathology. Most people, though, would speak carefully if they held such views and not write openly and emotionally about them in a diary that they intended to be published.

\subsubsection{Arthur Inman's Goals in Life}

Having settled into his cocoon-like existence, Inman had two goals. The first was to become a published and acclaimed poet. However, although he had a few poems published in newspaper and magazines, his books of poetry were published at his own expense (mainly in the 1920s) and never received critical acclaim. ${ }^{16} \mathrm{He}$ also edited the lettesr of George E. Pickett, a Confederate General in the American Civil War.

His second goal was to write the diary which he wanted to be published after his death. He wrote in it almost daily, then he edited each volume years later, and had much of it typed and then microfilmed. He set out to be completely honest in the diary - to record his life and thoughts uncensored. Even when he later regretted writing particular entries, he never changed them, even when he wrote about his wife or staff,

16 His efforts to write songs and plays were even less successful. 
people who would read the entries later as part of their work. This makes the diary similar to one by someone who never intends to have the diary made public. Inman hoped that the diary would make him famous after his death, but many times he had doubts about the value of the diary and whether it would bring him fame. Periods when he thought it was brilliant were often followed by periods of self-revulsion.

He wrote about social and political events, content which he thought would interest later readers. He also paid ordinary people to come and talk to him about their lives (initially for $\$ 1$ an hour) so that his diary is a record of the lives of people living in the 1900s. Despite his prejudices, people of all ethnicities and religions are included. In addition, several of his staff became particularly close to him, and he detailed their lives in more detail. It is this task that leads Maltsberger to label Inman a "psychological voyeur."

For many of his intimates, not only did he listen to them and record their lives, he tried to change them. He lectured them on attitudes and style. They turned to him for advice. He bought them clothes, changed their make-up, improved their speech and manners, and helped them set and achieve goals. The ends toward which he aimed were not always perhaps appropriate for his "pupils," and he was especially abusive (both verbally and physically) to his wife whom he hit in the early days of their marriage (acts which he later regretted and for which he apologized to her) and whose personality he could never accept. She was supposed to change to be the kind of woman he wanted, and he could not accept her as she was. A few of his intimates abandoned him after a few years and refused to ever visit him again, but others appreciated him and loved him, remaining close to him even after they married and moved away.

At the end of his life, a young 16-year-old girl ("Kathy Connor") moved into an apartment in his building. Aaron describes Kathy as pretty, poor, uneducated and Irish. Inman did cuddle and caress Kathy, but he never had sexual intercourse with her. Inman referred to Kathy as his "bewitching daughter.” He loved her, and she loved her surrogate father. (Her parents had divorced when she was two and neglected her.) He turned her into a "lady," and when she went to work as a saleswoman at Newbury Clothiers, Inman would have her driven to work in his car and enter by the front entrance rather than by the staff entrance. Aaron says: "Today Kathy feels indebted to him for his efforts to make her think well of herself” (p. 1583). Several of his intimates felt this way about Inman. Maltsberger (1994) called him "unloved.” This is not so. Even his wife, who had many fights with him, who separated from him from one brief period and who had a long-term affair with Dr. Pike that Inman knew nothing about at the time, loved him and was with him until his death.

In his interest in the minds and lives of other people and in his desire to change them for the better, I think that in modern times, with appropriate training, he might have made a good psychotherapist. After all, are not psychotherapists psychological voyeurs who wish to improve people for the better? Inman merely lacked the training and the appropriate setting for his goals. 
Inman had many doubts about his goals. He was forced eventually to accept that he was not a good poet. He read published diaries of others so that he could compare his with theirs. This would sometimes convince him of the worth of his own diary, but he also worried from time to time that his achievement as a diarist were poor. Although Aaron did publish some of the diary, it is not apparent whether any scholars have used it since its publication. It is ironic that it is Inman's suicide that made the diary of interest for the present paper.

\subsubsection{Sexuality}

Inman's first sexual intercourse was in 1922 with a woman he had hired to read books to him. The first time had little impact on him, but he reported that his "devils danced a bit" (p. 211) the second time, whatever that means. He was not able to "relieve" himself, and the same happened the first few times he had sex with his future wife, Evelyn, also in 1922.

Inman and Evelyn married in November, 1923. Inman had a limited sexual life with his wife. At times, his diary implies that sexual intercourse became rare and, in the best of times, Inman wanted intercourse no more than once a week. After Dr. Pike died in 1949, and Evelyn told him (in 1950) of her long-term affair with him, their sex life improved for a while, but it soon returned to its limited state. ${ }^{17}$

Leaving aside the cuddling and caressing with young women, Inman did have a few affairs (the first in 1932). Inman's wife knew about these, and later even volunteered to buy contraceptives for the women. After 1951, when Aaron's systematic excerpts from the diary cease, Inman did have sex with "Lillian" who was 17 when Inman met her, and with whom he had an exciting erotic relationship. They continued to be lovers after Lillian got married until she and her husband moved to Arizona. Lillian was followed by "Martha" whom he met in 1949 when she was 17 and who stayed his lover until 1956. Thereafter, Inman contented himself with girls between the ages of 12 and 15 with whom he did not have sex but merely touched and was touched.

Maltsberger, as we noted above, zeroed in on the Oedipal conflict in Inman. Let us explore this in more detail. Inman does note that his father never masturbated, and Inman never mentions masturbation himself. He seems to have problems in sexual intercourse. He mentions never experiencing passion. The one time he had sex with one of the women who slept naked in his bed with him, he appears to have been unable to ejaculate. There is no mention in the diary of the quality or quantity of

17 In an entry in 1933, he wrote, "Curse my impotence" (p 519), but it is not clear whether this is a sexual reference. 
sexual intercourse with his wife for him, but his wife found it unsatisfactory. ${ }^{18}$ The majority of his interactions with the women was like those of a child - touching, caressing, fondling - he of them and they of him. He never mentions any occasions on which they masturbated him.

Maltsberger noted that Inman was close to his mother and saw his father as an enemy. ${ }^{19}$ It is possible that Inman was a latent homosexual. One wonders whether the frail, slight, young Inman, sent off to the horrendous boarding school, was sexually abused by those boys who bullied him and what sexual role in life Inman might have chosen had he remained at home and attended local schools with peers who shared his social and subcultural background.

\subsubsection{Stressful Life Events}

Aside from his chronic pain and invalidism, Inman experienced a number of stressors during his life. Staff to whom he grew close (he often spoke sincerely of loving them) left. His poetry was consistently rejected for publication and judged to be poor. His mother died in 1933 and his father in 1951. His wife had breast cancer and a mastectomy in $1947^{20}$ After Dr. Pike's death in 1949, Inman learned of his wife's affair, and she left him in 1951, although she agreed to return after a few months apart. It is interesting than none of these events led him to plan or attempt suicide.

\subsubsection{Finding a Meaning in Life}

Victor Frankl (1963) proposed that the striving for meaning for one's life is a primary motivational force in people. The desire for such a meaning is as basic as the desire for power or for pleasure. Once we find the meaning, then life becomes more bearable. Following Nietzsche, Frankl noted that those who have a "why" to live can bear any "how."

Frankl noted that life has no general meaning. There is no abstract meaning that is true for all people. The meaning of life differs for each person and from day to day. Life has only a specific meaning for you at this moment. Each of us must find our own specific mission and concrete assignments in life. Each of us is questioned by life, and each of us must answer for our own life.

18 After the death of Dr. Pike, and his wife's confession of the affair, she coached him on how he should make love to her. However, she soon refused sex again, encouraging him to find satisfaction with other women, even though she admitted to mild jealousy (e.g., p. 1451)

19 He saw the male body as beautiful and the female body as "a weak collection of curves" (p. 273).

20 After this, she became more independent and stood up to Inman more than she had in the past. 
How do we discover the meaning of our lives? Frankl suggested that we may do a deed of some kind and thereby achieve or accomplish something (creative values). We may experience a value, such as a work of nature or a cultural object or a person, as when we fall in love with someone (experiential values). We may suffer, and suffering is a very common path toward finding a meaning for life. We can face our fate without flinching (attitudinal values).

If life is meaningful, then all the parts of life have a meaning, including suffering. What is critical is the attitude we take toward suffering-the attitude in which we take our suffering upon ourselves. (This suffering must be necessary and unavoidable. A person who suffers from an illness because he refuses to get a cure from a doctor is suffering unnecessarily.) We can accept our fate (and our suffering) with dignity and with an unselfish attitude, or we can whine and rage. It is important to have right action and right conduct. Life ultimately means taking upon ourselves the responsibility to find the right answers to its problems and to fulfill the tasks that life sets us. We end up, therefore, not in a tensionless state, but with a striving and struggling for some goal worthy of us.

Inman found meaning in his work. He tried two paths - as a poet and as a diary writer. He failed as a poet, but he maintained a hope throughout his life that his diary would be found valuable after his death. Although he had doubts from time to time about the value of his diary, he always returned to his hope that it was indeed a worthy endeavor.

Inman suffered, both physical pain and psychache (Shneidman, 1996), and he communicated this to his wife, servants and companions. His diary perhaps served as an outlet, a place where he could write about his pain and, thereby, spare those around him some of his complaining. Frankl noted that it is the attitude that we take toward our suffering that can make the suffering meaningful, but it seems that Inman never found meaning in his suffering, and his suicide was an escape from suffering that appeared to Inman to have no meaning.

\subsubsection{Suicidality}

As Shneidman (1994) noted, Inman was chronically suicidal all of his life, with 50 or so entries on death and suicide from 1912 to his suicide in 1963. Inman was in great psychological pain throughout his life. Inman wrote about hating life in 1925, and wondered why he did not kill himself in 1927. He thought seriously about shooting himself in 1929 (his wife had hid his gun) and acquired chloroform and wrote suicide notes in 1934 (but decided not to kill himself). His depression was constant, and he often wrote that his life had been a failure (e.g., p. 941) and that he was a "nobody" (e.g., p. 914). Although he was good at manipulating people, he knew that it was his money that kept others close to him. He wrote that he lacked the fortitude to kill himself (e.g., p. 791) 
In writing about his suicidal desires, he sometimes mentioned his aversion to noise in these early years and the pain from his medical problems. He wrote that, if his doctor (Dr. Pike) was no longer available, he would kill himself. He also laid the blame for his miserable psychological state on the five years he spent boarding at the high school. He often thought of himself as a failure.

May 23 [1930]. I certainly am miserable, dispirited, downcast. My nerves are piling up for another migraine. I see double and that with pain. I wish to God I were dead. Once upon a foolish time I considered myself gifted with brains, endowed with some especial talent, given to thinking unusual ideas. Now I realize sadly that I am not unusually talented in any way, in fact a failure among failures, a nobody. (p. 415)

Inman's first suicide attempt was in 1941. Nothing much had changed in his life at that point except that the traffic patterns had changed on Huntington Avenue outside the apartment building in which he lived. ${ }^{21}$ The noise and the traffic lights upset him and disturbed his sleep. On November $19^{\text {th }}$, he had his chief aide nail rugs over the windows, and he began to write of killing himself. (Remember that he lived most of the time in his darkened apartment, listening to books for the blind or having books read to him. His life was similar in some ways to living in a small dungeon.) On November $27^{\text {th }}$, he took an overdose of sleeping pills (nembutol and Veronal), and his aide found him at 7.30 am the next day. Initially, his wife left him without medical help until after $1 \mathrm{pm}$, and she argued with the doctors in the hospital to let him die. Inman declared himself proud of her. She never called him selfish, nor did she cry in front of him. Inman wrote on December $3^{\text {rd }}$, "I wish the doctors had let me die" (p. 1047). However, he did not attempt suicide again until 1963. He was pleased that he had the courage to attempt suicide, but he wished that the doctors had let him die.

In 1963, Inman's life continued in pretty much the same style, except that he was getting older and there was a major change in his living conditions. The apartment building in which he lived was very close to what became the Prudential Center. Buildings all around his apartment were torn down, and construction commenced on the 52-story building. The other change was that Inman's wife was drinking more heavily (she eventually joined AA), and Inman's consumption of alcohol also increased.

He took an overdose of sleeping pills in March 1963, was found by his housekeeper and ended up in Massachusetts General Hospital. Rather than move back to his apartment, he moved to an apartment hotel in Brookline. He could not adjust to the change, especially the new noises. Aaron described him as bored, irritable, nothing could distract him for long: not sex or reading or cuddling little girls. "I feel a harried ninety years old," he wrote, "with gathering pressures closing in about. I have lived too long. I have written too much.”.....He confessed himself a failure and doubted that his work would survive - it would have been better for himself and everyone

21 There was some ongoing stress in his marriage, but this was present throughout their marriage. 
connected with him if he had died in 1941..... On December 4 [1963] he reported: “This has truly been a session in hell. Eight migraines yesterday, and one more at six this morning, with violent headaches and nausea.” (p. 1598)

Inman knew that overdoses would not bring certain death, and so he shot himself on December $6^{\text {th }} 1963$.

\subsection{Discussion}

Arthur Inman lived 68 years. For all of his adult life, he was in chronic intense physical pain, and he lived a severely restricted life - staying in his darkened apartment almost all of the time. He had an unsatisfactory marriage, and those he paid to attend to him and to whom he grew close left him after a few years of service. He aspired to be a successful poet, but failed. He hoped that his diary would bring him fame after his death, but he often doubted that it would. The only pleasures in his life seemed to come from the books that were read to him $^{22}$ and political news, and from his interactions, social and sexual, with others. He experienced several stressors (parental deaths, marital rifts, and the loss of close friends), but he weathered these well.

What precipitated his suicide attempt in 1941 and his death in 1963 was the disruption to his life caused by the noise and chaos near his apartment. The tremendous change brought about by the construction of the Prudential Center was the stressor that he could not survive. He could not face leaving his "cocoon" in order to live elsewhere. One wonders whether, had the Prudential Center not been built, how long he would have lived. I suspect that he would have died from natural causes.

Stack and Wasserman (2007) applied Agnew's (1992) General Strain Theory to suicide. Agnew described several economic-related strains, including economic goal blockage, economic loss, and economic noxious stimuli. The category of economic loss included loss of property including one's home. Of the 675 suicides studied, Stack and Wasserman found evidence of economic-related strains in 67 suicides, and ten of these suicides had loss of a home as a precipitant. Inman's home was a tremendously important, secure and safe place for him, and the prospect of losing it was catastrophic for him.

What is surprising is that this "repulsive weakling," "warped personality" and "corrupt" individual should have lived so long and that the noise of construction and traffic should have precipitated his suicide. Indeed, it is impressive that he was able to construct a life that was full and during which he helped, with both advice and financial support, so many other people.

Pennebaker (1997) has shown that writing about emotional and traumatic experiences has a beneficial impact on physiological functioning (such as immune function),

22 He also listened to recorded books. 
behaviors (such as work performance), and mental health (see also Lepore \& Smyth, 2002). Pennebaker speculated that writing has these impacts because of self-disclosure and because of cognitive changes such as reduced rumination and increased assimilation of unexplained experiences. Most diaries are written privately, and only the writer reads them (at least while the writer is alive). Inman's diary differs in this respect. Not only did his wife read the entries, but also Inman employed members of his inner circle to type his handwritten diary (and eventually to microfilm it). Thus, those about whom he was writing often read what he wrote about himself and about them. Inman's diary, therefore, had the importance component of self-disclosure which is considered to be a beneficial therapeutic tactic (Jourard, 1971).

Lester and Terry (1992, 1993-1994) suggested, in discussing the lives of poets such as Anne Sexton and Sylvia Plath, that their poetry may have enabled them to continue living. Had they not been able to express their inner most thoughts and emotions in their writing, they might have killed themselves much earlier in their lives. It is possible, therefore, that it was Inman's diary that enabled him to live. In addition to giving his life a purpose (providing a record of his times that he hoped would bring him posthumous fame), it also gave him an outlet for his thoughts and emotions, a way of ventilating and exorcizing his inner demons and, in this way, enabled him to continue living. 